\title{
Maluliyet Raporlarının Düzenlenmesi: Anabilim Dalımıza Başvuran Olgu Özellikleri İle
}

\author{
The Arrangement of Disability Reports: by the Features of the Cases Applied to Our \\ Department
}

\author{
Ahsen Kaya, Orhan Meral, Nihal Erdoğan, Ekin Özgür Aktaş
}

Ege Üniversitesi Tip Fakültesi Adli Tip Anabilim Dah, İzmir

*Bu çalsşma 4-6 Haziran 2015 tarihlerinde Isparta'da düzenlenen XII. Adli Bilimler Kongresi’nde poster bildiri olarak sunulmuştur.

\section{Özet}

Amaç: Maluliyet raporlarının düzenlenmesi Adli Tibbın rutin uygulamalarından biridir. Bilirkişinin bu konudaki hukuki sorumluluğu, maluliyet raporlarının düzenlenmesi konusunun önemini arttırmıştır. Bu çalışmada, Ege Üniversitesi Tıp Fakültesi Adli Tıp Anabilim Dalına maluliyet raporu almak için başvuran olguların sosyodemografik ve tıbbi özellikleri ile maluliyet raporları konusunda bilirkişilerin sorumlulukları ve rapor hazırlanırken dikkat edilmesi gereken unsurların vurgulanması amaçlandı.

Gereç ve Yöntem: EÜTF Adli Tıp Anabilim Dalında 01.01.201131.12.2014 tarihleri arasında düzenlenen maluliyet raporları, olguların yaş, cinsiyet, meslek, rapor tarihi, istem makamı, olay türü, olay tarihi, konsültasyonlar, tanı, arıza çeşidi, maluliyet oranı, iyileşme süresi,

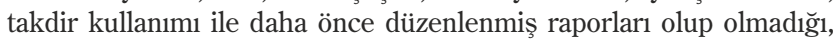
varsa raporlar arasındaki farklılıklar açısından değerlendirildi. Veriler istatistik programı ile analiz edildi.

Bulgular: İncelemenin yapıldığı 4 yılda 319 maluliyet raporu düzenlendiği, rapor sayısının yıllara göre arttığı gözlendi. Olguların 237'si erkek ve 82'si kadındı. Yaş ortalaması 38,5 $\pm 15,1$ olup, \%74'ünün $(\mathrm{n}=236)$ trafik kazası nedeniyle yaralandığı ve ortopedik arızaların ön plana çıktığı saptandı. On sekiz olguda maluliyet oranı $\% 100$ 'dü.

Sonuç: Bilirkişiler yasal mevzuatta kişideki arızanın tam karşılı̆̆ını bulamadıklarında takdiren bir arızayı seçebilmekte ya da maluliyet oranını düşürebilmektedirler. Bu durum farklı bilirkişiler tarafından farklı oranlar içeren raporların düzenlenmesine neden olmaktadır. Yine iyileşme süreci tamamlanmadan düzenlenen raporlar ile sonrasında düzenlenen raporlar arasında da sıklıkla oran farklılıkları oluşabilmektedir. Yönetmelikte ihtiyaçlar doğrultusunda değişiklik yapılması, rapor prosedürünün tekrar tanımlanması ve takdirin kullanım şekli ile ilgili bir düzenleme getirilmesi gerektiği düşünülmektedir.

Anahtar Kelimeler: Adli Tıp, Maluliyet, Bilirkişi.

\section{Abstract}

Objective: Arrangement of disability reports is one of the routine practices of forensics. Experts' legal responsibilities on this subject have enhanced the importance of arrangement of disability reports. In this study, it is aimed at emphasizing the responsibilities of experts on disability reports and the factors to be considered during preparation of reports by sociodemographic and medical features of the cases applied to The Forensics Department of Ege University Faculty of Medicine.

Materials and Methods: The disability reports prepared between 01.01.2011-31.12.2014 were evaluated in terms of age, sex, occupation, date of report, the authority of claims, the type of event, the date of event, consultations, diagnosis, the disability type, the disablement degree, and recovery period of cases and also whether if there is a discretion usage within the decision, reports prepared before and the differences between reports were also evaluated. Data analyzed by statistical program.

Results: It was observed that 319 disability reports prepared and the number of the reports increased according to the years within 4 years during which the examination was conducted. 237 cases were male and 82 were female. The mean age was $38.5 \pm 15.1$. $74 \%$ of them were injured due to the traffic accident and the orthopedic defects came into prominence. The disablement degree was $100 \%$ within 18 cases.

Conclusion: Experts could choose a disability type or decrease the disability degree by their discretion, if they don't find the disability type or disablement degree in legislation. This situation causes arrangement of the reports with different disablement degrees by different experts. Also the differences may frequently occur between the reports prepared before and after the recovery time. It is considered that a modification must be made in line with requirements of the regulation, the procedure of report must be redefined and an arrangement must be made regarding the usage style of discretion.

Keywords: Forensic Medicine, Disability, Expert witness.

\section{Giriş}

Maluliyet raporlarının düzenlenmesi Adli Tıbbın rutin uygulamalarından biri olup, tazminat davalarında adli tıp uzmanlarından başta maluliyet oranı ve iyileşme süresi olmak üzere çeşitli konularda rapor düzenlemeleri istenmektedir (1).

Maluliyet raporlarının olay tarihinde yürürlükte olan ilgili yasal mevzuata göre düzenlenmesi esastır. Son olarak, 17
Nisan 2014 tarih ve 2014/5990 karar nolu Yargitay ilamında da bu durum vurgulanmıştır (2). Ülkemiz yasal mevzuatında maluliyet oranlarının hesaplaması amacıyla çıkarılan tüzük ve yönetmelikler zaman içinde değiştirilmiştir. 22 Haziran 1972 tarih ve 14223 sayılı Resmi Gazete'de yayınlanarak yürürlüğe giren "Sosyal Sigorta Sağllk İslemleri Tüzüğü"nü (3) srrasiyla 11 Ekim 2008 tarihli ve 27021 sayılı Resmi Gazete'de yayınlanarak yürürlüğe giren "Çalışma Gücü ve Meslekte Kazanma Gücü Kaybı Oranı Tespit İşlemleri Yönetmeliği” (4) ve 3 Ağustos 2013 tarih ve 28727 sayılı Resmi Gazete'de yayınlanarak yürürlüğe giren "Maluliyet Tespiti İslemleri Yönetmeliği” izlemiştir (5). 
6100 sayılı Hukuk Muhakemeleri Kanunu'nun 266-287. maddelerine göre, bilirkişilere yüklenen hukuki sorumluluk maluliyet raporlarının düzenlenmesi sırasında da geçerlidir. Buna göre, "Bilirkişinin kasten veya ağır ihmal suretiyle düzenlemiş olduğu gerçeğe aykın raporun, mahkemece hükme esas alınması sebebiyle zarar görmüs olanların, bu zararn tazmini için Devlete karşı tazminat davası açabileceği, Devletin de ödediği tazminatı sorumlu bilirkişiye rücu edebileceği" belirtilmiş olup (6), bu durum bilirkişi açısından tazminata esas olan maluliyet raporlarının düzenlenmesi konusunun önemini daha da arttırmaktadır.

Bu çalışmada, Anabilim Dalımıza maluliyet raporu almak için başvuran olguların özellikleri ile maluliyet raporu düzenleyen bilirkişilerin sorumlulukları ve karşılaştıkları sorunların, rapor hazırlanırken dikkat edilmesi gereken unsurların vurgulanması, ayrıca maluliyet olgularının değerlendirilmesi ve rapor aşamasında belli standartların sağlanması için gerekli düzenlemelerin yapılması gerekliliğine dikkatçekilmesi amaçlandı.

\section{Gereç ve Yöntem}

Ege Üniversitesi Tip Fakültesi Klinik Araştırmalar Etik Kurulu'ndan alınan izin sonrası Adli Tip Anabilim Dalında 01.01.2011 - 31.12.2014 tarihleri arasında düzenlenen maluliyet raporları geriye dönük olarak tarandı. Olgulara ait kayıtlar; cinsiyet, yaş, doğum yeri, meslek, rapor tarihi, istem makamı, olay türü, olay tarihi, müracaat tarihi, istenilen tetkik ve konsültasyonlar, konulan tanı, saptanan arıza çeşidi, yaralanmanın tıbbi iyileşme süresi, hesaplanan maluliyet oranı, hesaplamada takdir kullanılıp kullanılmaması ve varsa daha önce şahıslara düzenlenmiş raporlar arasındaki farkllıklar açısından değerlendirildi.

\section{İstatistiksel Analiz}

Elde edilen veriler hazırlanan olgu rapor formlarına kaydedildi ve bilgisayar ortamina girildi. Verilerin SPSS programı (versiyon 18.0) ile frekans analizleri yapıldı. Demografik veriler ortalama değer \pm standart sapma ve/veya yüzde olarak ifade edildi.

\section{Bulgular}

İncelemenin yapıldığg 4 yılda 319 maluliyet raporu düzenlendiği, raporu düzenlenen olguların 237'sinin (\%74,3) erkek ve 82 'sinin $(\% 25,7)$ kadın olduğu saptandı. Olguların yaşları 5 - 84 arasında değişmekte olup, yaş ortalaması $38,5 \pm 15,1$ 'di. Onarlı yaş gruplarına ayrıldığında her iki cinsiyette de 30-39 yaş aralığında başvuru oranının en fazla olduğu görülddü (Tablo 1). Rapor sayısının yıllara göre arttığı gözlendi (Grafik 1).
Tablo 1. Olguların yaş grupları ve cinsiyete göre dağılımı.

\begin{tabular}{|l|r|r|r|r|}
\hline \multirow{2}{*}{$\begin{array}{l}\text { Yas } \\
\text { gruplan }\end{array}$} & \multirow{2}{*}{ Erkek } & \multirow{2}{*}{ Kadın } & \multicolumn{2}{|c|}{ Toplam } \\
\cline { 3 - 5 } & & & \multicolumn{1}{c|}{$\mathbf{n}$} & \multicolumn{1}{c|}{$\%$} \\
\hline $0-9$ & 4 & 1 & 5 & 1,6 \\
\hline $10-19$ & 18 & 4 & 22 & 6,9 \\
\hline $20-29$ & 48 & 12 & 60 & 18,8 \\
\hline $30-39$ & $\mathbf{7 2}$ & 22 & $\mathbf{9 4}$ & $\mathbf{2 9 , 5}$ \\
\hline $40-49$ & 49 & 21 & 70 & 21,9 \\
\hline $50-59$ & 27 & 9 & 36 & 11,3 \\
\hline $60-69$ & 14 & 9 & 23 & 7,2 \\
\hline $70-79$ & 2 & 3 & 5 & 1,6 \\
\hline $80-89$ & 3 & 1 & 4 & 1,2 \\
\hline Toplam & $\mathbf{2 3 7}$ & $\mathbf{8 2}$ & $\mathbf{3 1 9}$ & $\mathbf{1 0 0 , 0}$ \\
\hline
\end{tabular}

* Diğer: Kesici - delici alet yaralanması $(n=6)$, Düsme $(n=4)$,

Darp ve kesici - delici alet yaralanması $(n=3)$, Ateșli silah yaralanması $(n=1)$.

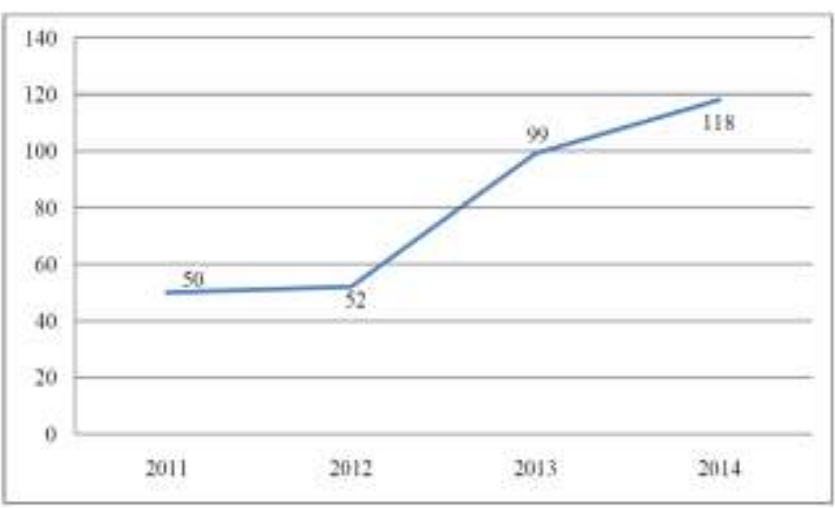

Grafik 1. Düzenlenen maluliyet raporlarının yıllara göre dağılımı.

Maluliyet raporu düzenlenmesi istenen olgular, farklı makamlarca Anabilim Dalımıza gönderilmiş olup, raporların \%76,5'inin (n=244) Asliye Hukuk Mahkemelerince istendiği (Grafik 2), olay türüne göre en sık trafik kazası $(\mathrm{n}=236, \% 74)$ sonucu başvuru yapıldı̆̆ı görüldü (Tablo 2).

Meydana gelen olay ile Anabilim Dalımızdan rapor düzenlenmesi için istemde bulunulan zaman karşılaştırıldığında, bu sürenin 1 - 16 yıl arasında değiştiği, olguların yalnızca 46'sının $(\% 15,3) 1$ yıl içerisinde başvurduğu saptandi. Olay tarihi ile müracaat tarihi arasında geçen süreler Tablo 3’te gösterildi.

Olguların 306’sının (\%95,9) Anabilim Dalımıza müracaatı sonrasında, 13 'ünün de $(\% 4,1)$ evrakı üzerinden raporlarının düzenlendiği, raporların 144'ünde $(\% 45,1)$ tıbbi iyileșme sürelerinin de belirtildiği tespit edildi. 
Tablo 2. Rapor istemine neden olan olay türleri.

\begin{tabular}{|l|c|c|}
\hline Olay Türü & Sayı (n) & Yüzde (\%) \\
\hline Trafik kazası & 236 & 74,0 \\
\hline Iş kazası & 38 & 11,9 \\
\hline Darp & 23 & 7,2 \\
\hline Digger* & 14 & 4,3 \\
\hline $\begin{array}{l}\text { Tibbi uygulama } \\
\text { hatası }\end{array}$ & 3 & 1,0 \\
\hline Emeklilik & 3 & 1,0 \\
\hline Mobbing & 3 & 0,6 \\
\hline Toplam & $\mathbf{3 1 9}$ & $\mathbf{1 0 0 , 0}$ \\
\hline
\end{tabular}

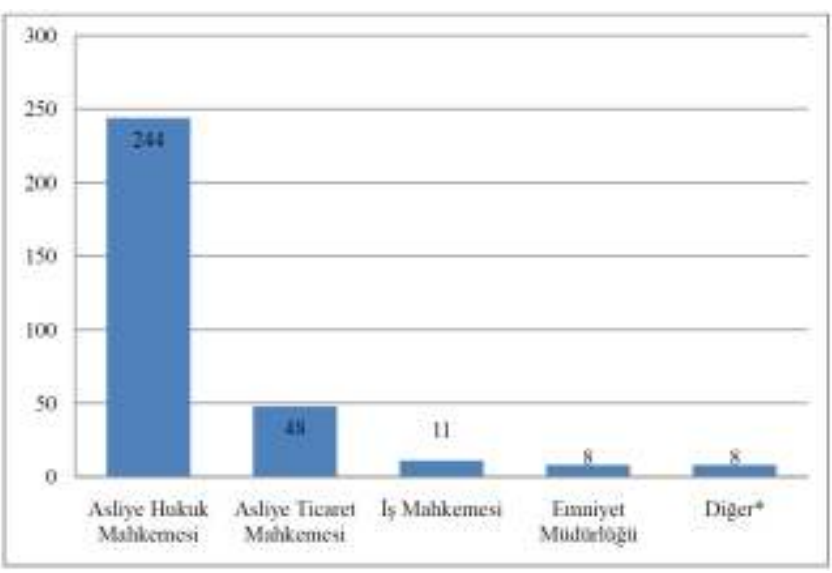

* Diğer: Sulh Hukuk Mahkemesi (n=3), Sosyal Güvenlik Kurumu ( $n=2)$, Jandarma Karakol Komutanlığı $(n=1)$, Garnizon Komutanlığı $(n=1)$, Türkiye Isş Bankası $(n=1)$.

Grafik 2. Anabilim Dalımızdan maluliyet raporu düzenlemesini isteyen makamların dağılımı.

Anabilim Dalımızda yapılan muayeneler sonucu 284 (\%89) olguya toplamda 489 konsültasyon istendiği, bunların sonucunda da $259(\% 81,2)$ olguya tetkik yapıldığı saptandı. En fazla istenen Ortopedi konsültasyonunun ( $\mathrm{n}=217)$ 177'sinin $(\% 81,6)$ trafik kazası sonucu başvuran olgulara istendiği görülmüss olup, konsültasyon istenen bölümler ile olay türü karşılaştırması Tablo 4’te gösterildi.

Anabilim Dalımıza müracaat eden 306 olgunun olay tarihinde yaptıkları işler ve meslekleri sorgulandığında, olguların 235’inin $(\% 76,8)$ ilgili yönetmelik ek listede belirtilen iş kollarına göre düz işçi olarak değerlendirildiği görüldü. Evrak üzerinden raporu düzenlenen 13 olgunun ise rapor düzenlenmesi için gönderilen evrakında mesleklerinin belirtilmediği, bunların 6'sının sadece tıbbi iyileşme süresinin sorulması, 1'inin maluliyetinin bulunmaması, 1'inin de her
Tablo 3. Olay tarihi ile müracaat tarihi arasında geçen süre.

\begin{tabular}{|l|c|c|}
\hline Başvuru süresi & Sayı (n) & Yüzde (\%) \\
\hline 1 yll ve daha az & 46 & 15,3 \\
\hline 2 yl & 75 & 24,9 \\
\hline 3 yll & 66 & 21,9 \\
\hline 4 yll & 39 & 13,0 \\
\hline 5 yll & 26 & 8,6 \\
\hline 6 yl & 12 & 4,0 \\
\hline 7 yll & 18 & 6,0 \\
\hline 8 yll & 5 & 1,7 \\
\hline 9 yl & 7 & 2,3 \\
\hline 10 yll ve izzeri & 301 & 100,0 \\
\hline Toplam* & & 2,3 \\
\hline
\end{tabular}

* 13 olguya Anabilim Dalımıza müracaat etmediğinden, 5 olguya da olay tarihi ile ilgili tam bir tarih elde edilemediğinden tabloda yer verilmemistir.

meslek grubu için maluliyet oranının $\% 100$ olması nedenleriyle meslek grup numarasına ihtiyaç olmaksızın raporu düzenlenmiş, kalan 5 rapor düzenlenirken ise olguların düz işçi olarak kabul edildikleri ancak istendiği takdirde kişilerin belirtilecek olan mesleklerine göre de yeniden hesaplama yapılabileceğinin belirtildiği görüldü. 102 (\%32) olgunun ilgili yönetmelikte mesleğinin karşılığı bulunmaması nedeniyle mesleğine en yakın meslek grubu seçildiği saptandı.

Muayene ve konsültasyonlar sonrası 319 olgunun 46'sinda $(\% 14,4)$ herhangi bir arıza saptanmamış olup, maluliyet tayinine yer olmadığına karar verildiği, $22(\% 6,9)$ olgunun sadece tıbbi iyileşme süresinin belirtilmesinin istendiği, 30 $(\% 9,4)$ olgunun psikiyatrik şikâyetlerinin kalıcı olup olmadığının belirlenebilmesi için takip ve tedavi önerildiği, 2 $(\% 0,6)$ olgunun olay öncesi görme ve işitme bilgisinin bulunmaması nedeniyle illiyetinin kurulamadığı, raporu dosya üzerinden düzenlenen $1(\% 0,3)$ olgunun ise çekilecek Manyetik Rezonans Görüntüleme sonucu ile değerlendirilebileceği belirtilerek maluliyet oranının hesaplanmadığ 1 tespit edildi.

Arıza saptanan $218(\% 68,4)$ olgunun arızalarının ilgili yönetmelikte belirtilen listelere göre dağılımı Tablo 5’te verilmiş olup, en sık pelvis ve alt ekstremite arızalarına $(n=200$, \%54,5) rastlandı. Ayrıca bu olguların ilgili yönetmeliğe göre hesaplanan maluliyet oranları gruplandırılması Tablo 6'da gösterilmiş olup, olguların \%73,4'ünün maluliyet oranının 
Tablo 4. Konsültasyon istenen kliniklerin olay türüne göre dağılımı.

\begin{tabular}{|c|c|c|c|c|c|c|c|c|}
\hline Klinikler & $\begin{array}{l}\text { Trafik } \\
\text { Kazası }\end{array}$ & $\begin{array}{l}\text { İs } \\
\text { Kazası }\end{array}$ & Darp & $\begin{array}{l}\text { Tibbi } \\
\text { Uygulama } \\
\text { Hatasi }\end{array}$ & Mobbing & Emeklilik & Diğer & Toplam \\
\hline Ortopedi & 177 & 28 & 3 & 0 & 0 & 1 & 8 & 217 \\
\hline Psikiyatri & 63 & 8 & 2 & 1 & 2 & 0 & 6 & 82 \\
\hline Nöroloji & 38 & 3 & 3 & 2 & 0 & 0 & 2 & 48 \\
\hline Diğer* & 22 & 1 & 2 & 1 & 0 & 4 & 1 & 31 \\
\hline Göz & 20 & 4 & 4 & 0 & 0 & 0 & 0 & 28 \\
\hline $\begin{array}{l}\text { Plastik, Rekonstrliktif ve } \\
\text { Estetik Cerrahi }\end{array}$ & 14 & 3 & 2 & 0 & 0 & 0 & 0 & 19 \\
\hline Göğus Hastalıkları & 14 & 0 & 1 & 0 & 0 & 1 & 1 & 17 \\
\hline $\begin{array}{l}\text { Kulak, Burun ve Boḡaz } \\
\text { Hastaliklan }\end{array}$ & 11 & 1 & 4 & 0 & 0 & 0 & 0 & 16 \\
\hline Beyin Cerrahisi & 12 & 2 & 1 & 0 & 0 & 0 & 0 & 15 \\
\hline Üroloji & 5 & 1 & 0 & 1 & 0 & 0 & 1 & 8 \\
\hline Radyoloji & 8 & 0 & 0 & 0 & 0 & 0 & 0 & 8 \\
\hline Toplam** & 384 & 51 & 22 & 5 & 2 & 6 & 19 & 489 \\
\hline
\end{tabular}

* Diğer: Cocuk ve Ergen Ruh Sağlığ ve Hastalıklarn ( $n=7)$, Genel Cerrahi ( $n=5)$, Kalp ve Damar Cerrahisi ( $n=5)$, Fiziksel Tip ve Rehabilitasyon

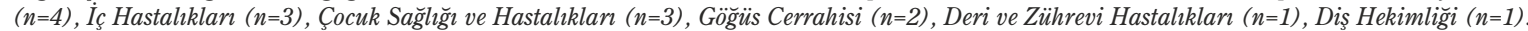

** 131 olgu için birden fazla bölümden konsültasyon istenmesi nedeniyle toplam konsültasyon sayısı toplam olgu sayısından fazladır.

Tablo 5. Olgularda tespit edilen arızaların arıza çeşidine göre dağılımı.

\begin{tabular}{|c|c|c|}
\hline Ariza Çeşidi & Sayn (n) & Yüzde (\%) \\
\hline Bas anzalan (1. Liste) & 45 & 12,3 \\
\hline Gözz anzalan (2. Liste) & 15 & 4,1 \\
\hline Kulak anzalan (3. Liste) & 2 & 0,5 \\
\hline Yiuz anzalan (4. Iiste) & 4 & 1.1 \\
\hline Goguts Hastaliklan (6. Liste) & 3 & 0,8 \\
\hline Omuz ve kol anzalan (7. Liste) & 46 & 12.5 \\
\hline El bilę̧i ve el anzalan ( 8 . Liste) & 3 & 0,8 \\
\hline El parmaklan anzalan (9. Liste) & 25 & 6,8 \\
\hline Omunga arizalian (10. Liste) & 12 & 3,3 \\
\hline Karm hastallklari ve arzzalarn (11. Liste) & 7 & 1,9 \\
\hline Pelvis ve alt ekstremite arzzalan (12. Liste) & 200 & 54,5 \\
\hline $\begin{array}{l}\text { Endokrin, Metabolizma, Kollagen Doku, Periferik Damar Hastalikları, } \\
\text { Hematolojik ve Romotoid Hastaliklan (13. Liste) }\end{array}$ & 4 & 1,1 \\
\hline Deri anzalar ve yantklar (14. Liste) & 1 & 0,3 \\
\hline Toplam * & 367 & 100,0 \\
\hline
\end{tabular}

* Olgularda birden fazla ariza saptanması nedeniyle toplam ariza sayısı toplam olgu sayısindan fazladir. 
Tablo 6. Tespit edilen maluliyet oranları gruplaması.

\begin{tabular}{|l|c|c|}
\hline Maluliyet oranı & Sayı (n) & Yüzde (\%) \\
\hline $0-9,99$ & 40 & 18,4 \\
\hline $10-19,99$ & 46 & 21,1 \\
\hline $20-29,99$ & 28 & 12,8 \\
\hline $30-39,99$ & 16 & 7,3 \\
\hline $40-49,99$ & 30 & 13,8 \\
\hline $50-59,99$ & 16 & 7,3 \\
\hline $60-69,99$ & 14 & 6,4 \\
\hline $70-79,99$ & 6 & 2,8 \\
\hline $80-89,99$ & 4 & 1,8 \\
\hline 100 & 218 & 18,3 \\
\hline Toplam & & 100,0 \\
\hline
\end{tabular}

Tablo 7. \%100 maluliyete neden olan arızaların dağglımı.

\begin{tabular}{|c|c|c|}
\hline Anzza çeşidi & Sayn (n) & Yüzde (\%) \\
\hline Frontal lob Sendromu & 5 & 27,7 \\
\hline $\begin{array}{l}\text { Nevrotik Bozukhuk } \\
\text { (Tedavi ile calıssma olanag̊a verneyeni) }\end{array}$ & 3 & 16,6 \\
\hline Omurga kanğ nedeniyle oluşan omurilik yaralanmas sonucu jarapleji gelişimi & 3 & 16,6 \\
\hline Kafa travmasına bağht parajaraż gelişimi (inkentinans ile birliktelik gösteren) & 2 & 11,1 \\
\hline $\begin{array}{l}\text { Kafa travmasına bağh konusma bozukluğu ve ag̃ar dizeyde paralizi gelişimi (inkontinans ile } \\
\text { birliktelik gösteren) }\end{array}$ & 1 & 5,6 \\
\hline Kafa travmasısa bağh parapleji gelişimi & 1 & 5,6 \\
\hline Kafa travmasına bağh ağar diizryde vertigo gelişimi & 1 & 5,6 \\
\hline Kafa travmasısa bağh ağor dibeyde amnezi geclişimi & 1 & 5,6 \\
\hline Poliarteritis Nodosa & 1 & 5,6 \\
\hline Toplam & 18 & 100,0 \\
\hline
\end{tabular}

Tablo 8. Olguların tıbbi iyileşme süreleri dağılımı.

\begin{tabular}{|l|c|c|}
\hline Tibbi iyileşme süresi & Sayı (n) & Yüzde (\%) \\
\hline 1 aya kadlar (1 ay hariç) & 20 & 13,9 \\
\hline 1 aydan 2 aya kadar (2 ay hariç) & 18 & 12,5 \\
\hline 2 aydan 6 aya kadar (6 ay harị) & 35 & 24,3 \\
\hline 6 aydan 12 aya kadar (12 ay hariç) & $\mathbf{5 9}$ & $\mathbf{4 1 , 0}$ \\
\hline 12 ay ve üzeri & 12 & 8,3 \\
\hline Toplam & $\mathbf{1 4 4}$ & $\mathbf{1 0 0 , 0}$ \\
\hline
\end{tabular}

\%50'nin altında olduğu, 18 olgunun ise \%100 malul olduğu görüldü. \%100 maluliyete neden olan arızalar Tablo 7'de gösterildi.

Sadece tıbbi iyileşme süresi sorulan 22 olgu ile birlikte toplam 144 olgunun raporunda tıbbi iyileşme (geçici işgöremezlik) süresi belirtilmiş olup, bunların 59'unun (\%41) tıbbi iyileşme süresinin 6 ay ile 1 yıl arasında değiştiği görüldüi (Tablo 8).

Maluliyet oranı hesaplanan 218 olgunun 78'inde $(\% 35,8)$ olaya bağlı meydana gelen arızanın karşılığı bulunmadığından ilgili yönetmeliğe göre arızasına en yakın arıza çeşidi seçildiği, olguların 15’inde ise yönetmelikte kişinin arızasına karşılık gelen arıza bulunmakla beraber o arızaya karşılık gelen fonksiyonun tamamı yitirilmediğinden açıklama yapılarak maluliyet oranında takdiren bir oran belirtildiği görüldü.

Anabilim Dalımıza başvurmadan önce 70 olgunun başka kurum ya da kurumlardan rapor almış olduğu görülmüş, 53 kişinin engelli sağlık kurulu raporu, 18 kişinin maluliyet raporu aldığı, her iki raporu da alan kişi sayısının ise 11 olduğu görüildü. 
ya da yitirilmesinden doğan kayıplar, ekonomik geleceğin sarsılmasından doğan kayıplar kastedilmektedir (8).

Maluliyet raporlarının değerlendirildiği bu çalışmada saptanan yaş, cinsiyet ve yaş aralığı verileri Ankara, İstanbul ve İzmir'de yapılan diğer çalışmalarla uyumlu bulunmuştur (1,911). Çalışmanın yapıldığı dört yıl içinde yıllara göre dağılıma bakıldığında rapor sayısının zaman içinde arttığı gözlendi. $\mathrm{Bu}$ durum, zaman içinde tazminat davalarının da arttığını düşündürmüştür.

Çalışmada maluliyet raporu isteyen makamlar arasında ilk sirada Asliye Hukuk Mahkemeleri'nin (AHM) (n=244, \%76,5) yer aldığ1 görüldü. Birgen ve ark.'nın 1994-1998 yılları arasında 139 olgu ile yaptığı çalışmada AHM'ler ve İş Mahkemeleri'nin (IM) birlikte ilk sırada olduğu belirtilmiştir (10). Cantürk’ün 1993-2003 yılları arasında başvuran 32 olgu ile yaptığ çalışmada ise AHM, IM'nden sonra ikinci sırada gelmektedir (9). Sulh Hukuk Mahkemelerinin görevleri dışında kalan ve özel hukuk ilişkilerinden doğan her türlü dava ve işlerde AHM'nin (12), işçi işveren ilişkisinde ise iş akdinden kaynaklanan her türlü uyuşmazlıkların çözülmesinde İM'nin (13) görevli olduğu düşünüldüğünde, çalışma hayatını ilgilendiren bu tür davalarda, çalışmalarda saptanan maluliyet oranı istem makamlarının dağılımlarının beklenen nitelikte olduğu görüildü.

Meydana gelen olay ile Anabilim Dalımızdan rapor düzenlenmesi için yapılan müracaat tarihleri arasında geçen sürelerin 1-16 yıl arasında değiştiği, olguların yalnızca \%15,3'ünün 1 yıl içerisinde başvurduğu saptandı. Eşiyok ve Korkusuz'un çalışmasında ise olguların \%28,8’inin ilk 1,5 yıl içerisinde başvurduğu belirtilmiştir (1). Anabilim Dalımıza başvuruların olayın üzerinden uzun bir süre geçtikten sonra yapılması, olguların maluliyet durumları ve tazminat davaları konusunda yeterli bilgi ve tecrübe sahibi olmamalarına, alınan raporlara karşı davalı tarafça yapılan itirazlar ve bunun sonucunda Anabilim Dalımızın rapor istenen ilk merkez olmaması ile adli sürecin yavaș ilerlemesine bağlanmıștır.

Meydana gelen olay türlerine bakıldığında, çalışmamızda en fazla trafik kazası ( $\mathrm{n}=236$, \%74) sonucu rapor başvurusu yapıldığg 1 görülmüş olup, bu durum Ertürk ve ark.'nın çalışması $(\% 74,3)$ ile Eşiyok ve Korkusuz’un $(\% 96,2)$ çalışması ile uyumlu bulunmuştur $(1,11)$. Trafik kazaları yaralanmalara yol açan kazalar arasında tüm dünyada ilk sırada yer almaktadır (14). Dünya Sağlık Örgütü’nün 2013 raporunda; dünyada her yıl yaklaşık 1,24 milyon kişinin trafik kazası sonucu hayatını kaybettiği, 20-50 milyon arasında kişinin de yaralandı̆̆ bildirilmektedir (15). Yaralanmalar sonucu 10 milyondan fazla kişinin de yaşamlarını kalıcı sakatlıklarla sürdürmek zorunda kaldığ ${ }_{1}$ belirtilmektedir (16).

Yapılan çalışmalarda, trafik kazalarında görülen yaralanmalar içerisinde baş-boyun bölgesi ile birlikte ekstremite lezyonlarının en sık görülen yaralanmalar olduğu belirtilmiştir $(17,18)$, Çalışmamızda pelvis ve alt ekstremite lezyonlarının maluliyete esas alınan arızalar arasında ilk sırada yer alması, Birgen (10) ve Eşiyok'un (1) çalışmaları ile de uyumlu olup, bu durum olay türleri içerisinde en sık trafik kazalarının bulunmasıyla ilişkilendirilmiştir.

Çalışmamızda toplam 489 konsültasyon istendiği, bunların sonucunda da olguların \%81,2'sine tetkik yapıldığ 1 saptandı. Meydana gelen olaylar nedeniyle kişilerin sağlık durumlarının bozulmasının yanı sıra, her yıl devletin ve işletmecilerin uğradığı ekonomik kayıpların ciddi boyutlara ulaştı̆̆ bilinmektedir. Rapor düzenleme sürecinde istenen konsültasyon ve tetkik sayısının fazlalığı, bu sürecin de ekonomik açıdan ciddi boyutlarda olduğunu göstermektedir.

Saptanan muayene bulguları ve istenen konsültasyonların birlikte değerlendirilmesi sonucunda 218 olgunun \%73,4’ünün maluliyet oranının \%50'nin altında hesaplandığı saptanmış olup, bu durumun literatürle uyumlu olduğu görülmüștür (10).

Rapor almak için Anabilim Dalımıza başvuran olguların \%76,8'i ilgili yönetmeliğe göre düz işçi olarak değerlendirilmiştir. Bu oran Cantürk ve ark.'nın çalışmasıyla $(\% 78,1)$ uyumludur (9). Yargitay 4. Hukuk Dairesinin 12.02.2002 tarih ve 2002/1844 Karar nolu kararında "beden gücü kaybına uğrayan davacının yaşadiğı sürece maluliyeti nedeniyle daha fazla efor sarf edeceği, çalışmıyor ve kazanç elde etmiyor olsalar bile günlük yaşamların sürdürürlerken sakatlıkları oranında zorlanacaklar» $(19,20)$ ve ayrica Yargitay 19. Hukuk Dairesinin 14.10.1993 tarih ve 7605 - 6582 Karar nolu kararında “...ev kadının da aynı şekilde kendi ev işlerini yaparken zorlanacağ düşüncesiyle ve asgari ücret baz alınmak suretiyle” tazminat isteme hakkının bulunduğu belirtilmiştir (21). Uygulamada, ilgili yönetmelikte meslek grup numaraları bulunmayan ev hanımı, emekli, öğrenci gibi kişilerin maluliyet oranının hesaplanmasında Yargıtay içtihatları göz önünde bulundurulmaktadir.

Maluliyet oranlarının hesaplanması amacıyla kullanılan ilgili yönetmeliğin ek listelerinde her mesleğin karşılığı olarak meslek grup numarası bulunmamakta olup, bu durumla sıklıkla karşılaşılmaktadır. Böyle bir durumla karşılaşan bilirkişi, çoğu zaman olgunun mesleğine en yakın meslek grubunu seçerek bu sorunu aşabilmektedir. Çalışmamızda 102 olgunun ilgili yönetmelikte mesleğinin karşılı̆̆ının bulunmaması nedeniyle hesaplama yapılırken mesleğine en yakın meslek grubunun seçildiği görülmektedir. Bazen de ek listede şahsın mesleğine yakın bir meslek grubu bulunmaması nedeniyle raporu istenen kişi düz işçi olarak kabul etmekte, bu durum hesaplamada değişikliğe yol açabilmektedir. Maluliyet tespitinde kullanılan yönetmelikte en son 2013 yılında 
değișiklik yapılmış olmakla birlikte, meslek grup numaraları ile ilgili ek listelerde herhangi bir düzenleme yapılmamıştır. Özellikle değişen çă̆ ile yeni meslek gruplarının ortaya çıkması ve bu mesleklerin pek çoğunun bu listelerde yer almamasının kişiler adına hak kayıplarına yol açabileceği düşünülmektedir. Ülkemiz koşullarında yapılan mesleklerin ve iş kollarının genel meslek gruplarını da içerecek şekilde güncellenerek ilgili yönetmelikteki meslek grup listelerinin düzenlenmesinin, maluliyet raporlarına olan itirazları azaltacağ 1 ve buna bağlı olarak dava sürelerinin uzamasını engelleyeceği düşünülmektedir.

Anabilim Dalımıza başvurmadan önce 70 olgunun başka kurumlardan da rapor aldığı görüldü. Alınan anamnez ve dosya incelemesinden, raporlara yapılan itirazların bu duruma neden olduğu anlaşılmıştır.

Meslekte kazanma gücünde azalma oran 1 hesaplamalarında itiraza konu olan başlıklar arasında, mağdurda meydana gelen ve fonksiyon kaybı oluşturan arızanın ilgili yönetmelikte aynen yer almaması nedeniyle şahsın arızasına en yakın arıza çeşidinin seçilmesi ya da ilgili yönetmelikte belirtilen fonksiyon kaybı düzeyinde bir kayıp olmaması nedeniyle oranda takdir hakkının kullanılarak değișiklik yapılması yer almaktadır. Tıbbi kıyas metodu olarak değerlendirilen bu durum yani yönetmelikte var olan bir hükmün ya da hükmün içerisinde var olan bir ilkenin hakkında hiçbir hüküm olmayan benzer bir olaya uygulanması durumu, hem değişik şekillerde beden fonksiyonlarını kaybetmiş kișilerin mağdur olmalarını engelleyecek, hem de binlerce bedensel arıza içinden ilgili yönetmeliğe yansıtılabilenler dışında olanların yarattığı kayıpların belirlenmesine yardımcı olacaktır. Elbette ki, burada da en son takdir hakkı hâkimdedir. Sonuçta, bilirkișilerin raporlarında yer alan takdiri değerlendirmelerinin bilimsel ve tıbbi gerekçelerini ve dayanaklarını uygun şekilde belirtmelerinin itirazları azaltacağ1 düşünülmektedir. Ayrıca her ne kadar Ceza Muhakemesi Kanunu (22) ve Hukuk Muhakemesi Kanunu (6) ile bilirkişinin belirlenmesinden görevlendirilmesine, yükümlülüklerinden yetkilerine, hatta gider ve ücretine kadar birçok yön açıklanmışsa da, takdir yetkisinden açıkça bahsedilmemektedir. Bu durum, özellikle maluliyet raporlarının hazırlanmasında önemli bir açığı kapatan takdir hakkının kullanımı konusunda bilirkișilerin tereddütte kalmasına yol açmaktadır.

İtiraza neden olan bir diğer önemli nokta, tıbbi lezyonların zaman içinde azalma ya da artma göstermesi nedeniyle, meslekte kazanma gücü azalma oranında değişikliğe neden olmasıdır. Sonuçta, iyileşme süreci tamamlanmadan düzenlenen raporlar ile daha sonra düzenlenen raporlar arasında da sıklıkla oran farklılıkları oluşabilmektedir. Bu durumlar, farklı bilirkişiler tarafından farklı oranlar içeren raporların çıkmasına neden olmaktadır. Mevcut tıbbi durumun tedavi/rehabilitasyonla değişebileceği durumlar söz konusu ise bilirkişilerin düzenledikleri raporlarda bu durumu belirtmeleri, oranın değişme olasılığının hakime bildirilmesi, Borçlar Kanunu Madde 75’e göre hakimin tazminat hükmünün değiştirme yetkisinin saklı kalması yönünde karar vermesine neden olabilir (8). Bu anlamda, bedensel zararlardaki varsa değişiklik olasılı̆̆gnın raporlanmamasının bilirkişinin sorumluluğunu ortaya çıkaracağı unutulmamalıdır.

Sonuç olarak, Adli Tip uzmanlarının bilirkişilikle ilgili yasal yetki ve sorumluluklarını işleri gereği bilmeleri bir zorunluluktur. Rutin uygulamalar içinde yer alan maluliyet raporlarının düzenlenmesi sırasında yapılan değerlendirmelerin gerekçeleri ile raporda belirtilmesinin, ilgili yönetmelikte ihtiyaçlar doğrultusunda yukarıda ayrıntılı olarak değinilen değișikliklerin yapılmasının, rapor prosedürünün tekrar tanımlanmasının ve takdirin kullanım şekli ile ilgili bir düzenleme getirilmesinin, hem itirazların önüne geçilmesini sağlayacağı, hem de olgunun bir başka bilirkişi tarafından değerlendirilmesi durumunda aydınlatıcı olacağı düşünülmektedir.

\section{Kaynaklar}

1. Eşiyok B, Korkusuz İ. Yaşlılarda Travmaya Bağlı Maluliyet. Turkish Journal of Geriatrics2006; 9(4):213-217.

2. Yargitay 17. Hukuk Dairesinin 17 Nisan 2014 tarihli ve 2013/6463 Esas 2014/5990 Karar Nolu İlam1.

3. Sosyal Sigorta Sağlık İșlemleri Tüzüŭü. 22.06.1972 Tarihli ve 14223 Sayılı Resmi Gazete. http://www.mevzuat.gov.tr/MevzuatMetin/ 2.5.74496.pdf. Erişim Tarihi: 01.07.2015

4. Çalıșma Gücü Ve Meslekte Kazanma Gücü Kaybı Oranı Tespit İşlemleri Yönetmeliği. 11.10.2008 Tarihli ve 27021 Sayılı Resmi Gazete. http://www.resmigazete.gov.tr/main.aspx?home=http: //www.resmigazete.gov.tr/eskiler/2008/10/20081011.htm\&mai n=http://www.resmigazete.gov.tr/eskiler/2008/10/20081011.ht m. Erişim Tarihi: 01.07.2015

5. Maluliyet Tespiti İşlemleri Yönetmeliği. 03.08.2013 Tarihli ve 28727 Sayılı Resmi Gazete. http://www.resmigazete.gov.tr/eskile r/2013/08/20130803-6.htm. Erișim Tarihi: 01.07.2015

6. 6100 Sayılı Hukuk Muhakemeleri Kanunu. 04.02.2011 Tarihli ve 27836 Sayll Resmi Gazete. http://www.resmigazete.gov.tr /main.aspx?home=http://www.resmigazete.gov.tr/eskiler/2011 /02/20110204.htm\&main=http://www.resmigazete.gov.tr/eskile r/2011/02/20110204.htm. Erișim Tarihi: 01.07.2015

7. Arslan MM, Eren A, Çekin N. Adana'da İș Kazalarına Bağlı Ölümler. Turkiye Klinikleri J Foren Med 2009;6(2):60-4

8. 6098 Sayılı Türk Borçlar Kanunu. 04.02.2011 Tarihli ve 27836 Sayılı Resmi Gazete. http://www.mevzuat.gov.tr/MevzuatMetin/ 1.5.6098.pdf. Erişim Tarihi: 01.07.2015

9. Cantürk G, Eşiyok B, Yaşar H, Doğan B, Hancı İH. İş Kazası Nedeniyle 1993-2003 Yılları Arasında AÜTF Adli Tip Anabilim Dalına Başvuran Olguların Değerlendirilmesi. Erciyes Tip Dergisi, 2006;28(1):1-6.

10. Birgen N, Okudan M, İnanıcı MA, Okyay M. İș kazasına bağlı olgularda maluliyet oranı hesaplanması: Adli tıp açısından değerlendirilmesi. Adli Tıp Bülteni, 1999;4(3):101-8. 
11. Ertürk S, Ege B, Yemişcigil A, Aktaş EÖ. Maluliyet Oranları Saptanan Olguların Özellikleri. 1.Ulusal Adli Tip Kongresi (1-4 Kasım 1994 İstanbul) Poster Sunuları Kitabı. İstanbul: Özgün Ofset Ltd Şti 1998:139-42.

12. 5235 sayılı Adli Yargı İlk Derece Mahkemeleri İle Bölge Adliye Mahkemelerinin Kuruluş, Görev Ve Yetkileri Hakkında Kanun 07.10.2004 Tarihli 25606 Sayll Resmi Gazete. http://www.mevzuat.gov.tr/MevzuatMetin/1.5.5235.pdf. Erişim Tarihi: 01.07.2015

13. 4857 sayılı İs Kanunu 10.06.2003 Tarihli 25134 Sayılı Resmi Gazete. http://www.mevzuat.gov.tr/Metin1.Aspx?MevzuatKod=1.5.4857 \&MevzuatIliski $=0$ \&sourceXmlSearch\&Tur $=1 \&$ Tertip $=5 \& N o=485$ 7. Erişim Tarihi: 01.07.2015

14. Dirlik M, Çakır Bostancıoğlu B, Elbek T, Korkmaz B, Çallak Kallem F, Gün B, Features of the traffic accidents happened in the province of Aydin between 2005 and 2011. Ulus Travma Acil Cerrahi Derg. 2014;20(5):353-8.
15. World Health Organization. Global status report on road safety 2013: supporting a decade of action. http://www.who.int /violence_injury_prevention/road_safety_status/2013/en/. Erişim Tarihi 01.07.2015

16. Pfortmueller CA, Marti M, Kunz M, Lindner G, Exadaktylos AK. Injury Severity and Mortality of Adult Zebra Crosswalk and NonZebra Crosswalk Road Crossing Accidents: A Cross-Sectional Analysis. Plos One. 2014;9(3):1-6.

17. Bilgin UE, Meral O, KoçakA, AktaşEÖ , Kıyan S, Altuncı YA. 2011 yılında trafik kazası sonucu Ege Üniversitesi Hastanesi Acil Servisine başvuran hastaların adli tıbbi boyutuyla incelenmesi. Ege Tip Dergisi / Ege Journal of Medicine 2013;52 (2):93-99

18. Koçak S, Uçar K, Bayır A, Ertekin B. Acil servise başvuran motorsiklet ve bisiklet kazası olgularının karakteristikleri. Türkiye Acil Tip Dergisi 10.3 (2010): 112-8. 